\title{
Influencing Factors on Students' Career Interests in Islamic Financial Institutions
}

\author{
Rima Dwijayanty ${ }^{1}$, Sukadwilinda ${ }^{2}$, Isep Sopian ${ }^{3}$ \\ ${ }^{1}$ Program Studi Akuntansi, Universitas Sangga Buana, Bandung, Indonesia \\ ${ }^{2}$ Program Studi Akuntansi, Universitas Sangga Buana, Bandung, Indonesia \\ ${ }^{3}$ Program Studi Akuntansi, Universitas Sangga Buana, Bandung, Indonesia
}

\begin{abstract}
The purpose of this research is to find out and analyze the factors that influence students' career interests in Islamic financial institutions, measured by variables of Islamic knowledge, career development and compensation. The development of Islamic economics in Indonesia has developed quite rapidly. One of them is the increasing number of Islamic-based financial institutions. This development certainly requires qualified human resources in the field of Islamic finance. However, the problem that occurs is the lack of graduates who are interested in a career in Islamic financial institutions. This research uses descriptive and associative methods. The data used are primary data in the form of questionnaires distributed to accounting students at Sangga Buana University YPKP who have taken Islamic accounting course. Based on the results of the study, it is seen that the variables of Islamic knowledge, career development and compensation simultaneously influence $37.9 \%$ of accounting students' career interests in Islamic financial institutions. This research shows an opportunity for universities to be able to open sharia-based majors.The opening of the sharia department aims to provide human resources capability to support improvement of the quality and quantity of Islamic financial institutions
\end{abstract}

Keyword. islamic financial institutions; islamic knowledge; career development; compensation

Article History. Received August, 2019. Revised October, 2019. Accepted December, 2019

Corresponding author.Email: rima.dwijayanty@usbypkp.ac.id,

sukadwilinda.ypkp@usbypkp.ac.id

How to cite article. Dwijayanty, R., \& Sopian, I. (2019). Influencing Factors on Students' Career Interests in Islamic Financial Institutions. The International Journal of Business Review (The Jobs Review), 2(2), 133-142. https://doi.org/https://doi.org/10.17509/tjr.v2i2.21492

\section{INTRODUCTION}

Currently, the development of Islamic economics has been very advanced and developed quite rapidly. In the two decades of development since the birth of the first Islamic bank in Indonesia, the Islamic financial system has developed rapidly. Not only Islamic banking, Islamic non-bank financial industry has also developed. For example, Islamic insurance, Islamic pension funds, Islamic finance companies, Islamic bonds (sukuk), Islamic mutual funds, and other Islamic capital market activities.

However, the growth of Islamic finance has not been able to offset the growth of conventional finance. This can be seen from the market share of Islamic finance which is still below $5 \%$ overall. The things that need to be done in accelerating the growth of Islamic finance in Indonesia is to conduct various programs that can solve various problems. The 
problems facing the Islamic financial industry include the limited supply of Islamic products; limited access to Islamic financial products; the low level of literacy of Islamic finance and level of utility of Islamic financial products; limited human resources; the need for optimization of coordination with stakeholders; and the need for financial services policies that are aligned and mutually supporting the development of the entire Islamic financial sector. (www.ojk.go.id)

With the problem of limited human resources in Islamic financial institutions, it is an opportunity for tertiary institutions to provide graduates who have capabilities in the Islamic field. One of the steps that can be taken is to bring up Islamic-based courses, for example for the bachelor's degree program of accounting at Sangga Buana University, with the choice of Islamic accounting course, where students get the basic knowledge of Islamic economics, especially Islamic-based transactions, both in theory and practice. In that way, students will have the knowledge that is the basis for considering their career in Islamic financial institutions.

Islamic accounting is an accounting for transactions that are in accordance with the rules set by Allah SWT (Nurhayati \& Wasilah, 2009). As a prospective undergraduate, an accountant must have a good understanding of the sources of value of the Islamic business itself if they want to enter this field. It is needed in order to be able to provide professional judgment, especially in dealing with conditions of uncertainty. The sustainability of the Islamic economic system depends very much on the trust of the people who are the stakeholders in it who demand transparency and accountability. Therefore, it needs the support of reliable and trusted Islamic accountants in managing Islamic entities (Andrian, 2015).

In addition, one of the most important aspects in the world of working is career certainty. From a career standpoint, the Secretary General of the Indonesian Association of Islamic Banks, Achmad K Permana, said that HR in Islamic banking is not inferior to conventional banking that is already saturated (kompas.com). Career determination by every student must certainly have an interest in the field. Career design and student interests are very useful for students. Career design will be the direction of student movement in achieving desired future goals. In addition to career design and interests that are useful for students, it also benefits academics in designing an educational curriculum will later be given to students. Career design and academic interest can create a learning process that is of interest to students which is certainly more effective. For example, providing specific guidance to determine future career plans in accordance with interests (Merdekawaty \& Sulistiawaty, 2011). In choosing a career to be undertaken, accounting students have various considerations to choose what career they will lead. The factors consist of work intrinsic value, financial reward / salary, work environment, professional training, professional recognition, social values and labor market considerations (Sutrisna \& Muchlis, 2016). Based on the phenomena explained above and based on previous researches, the writers found the problem to be discussed in this study namely the extent to which the factors of Islamic knowledge, career development and compensation affect the students' career interests in Islamic financial institutions both partially and simultaneously. 


\section{METHOD}

The research method used in this study is the associative method. The type of data used in this study is quantitative data that is obtained from respondents' answers to the questions in the questionnaire in the form of scores. The source of data used is primary data, i.e. data obtained directly from respondents in the form of answers to questionnaires. The primary data is collected through the results of distributing question sheets given to accounting students of regular afternoon class of 2015 at Sangga Buana University YPKP Bandung who have taken Islamic accounting courses and have work experience, with total 69 people. This is done because the majority of afternoon regular class students are students who already have work experience or are still working, so they have their own perspective in the Islamic accounting course. In determining the number of samples of this study, the writers use Slovin formula $n=\frac{\mathrm{N}}{1+\mathrm{N} \mathrm{e}^{2}}$

$$
n=\frac{69}{1+69(0,1)^{2}}=40,82=41 \text { People }
$$

The dependent variable in this study is the interest of the accounting students in determining their career in Islamic financial institutions. The independent variables in this study are: Islamic knowledge, career development, and compensation.Partial Test ( $\mathrm{t}$ Test)

The $t_{\text {test }}$ is used to test the hypothesis partially to show the effect of each independent variable individually on the dependent variable. $\mathrm{H}_{0}$ can be determined whether it is accepted or rejected, by comparing tcount with table with a significant level $(\alpha)$ of 0.05 or $5 \%$.

Partial Test (t Test)

The $t$ test is used to test the hypothesis partially to show the effect of each independent variable individually on the dependent variable. $\mathrm{H}_{0}$ can be determined whether it is accepted or rejected, by comparing tcount with ttable with a significant level $(\alpha)$ of 0.05 or $5 \%$. Test Criteria:

$\mathrm{H}_{0} 1: \beta_{1}=0$ there is no influence of Islamic knowledge on the students' career interests in Islamic financial institutions.

$\mathrm{H}_{\mathrm{a}} 1: \beta_{1} \neq 0$ there is influence of Islamic knowledge on the students' career interests in Islamic financial institutions.

$\mathrm{H}_{0} 2: \beta_{2}=0$ there is no influence of career development on the students' career interests in Islamic financial institutions.

$\mathrm{H}_{\mathrm{a}} 2: \beta_{2} \neq 0$ there is influence of career development on the students' career interests in Islamic financial institutions 
$\mathrm{H}_{0} 3: \beta_{3}=0$ there is no influence of compensation on the students' career interests in Islamic financial institutions.

$\mathrm{H}_{\mathrm{a}} 3: \beta_{3} \neq 0$ there is influence of Compensation on the students' career interests in Islamic financial institutions.

Conclusions of tcount in making decisions:

a. If $t_{\text {count }}>t_{\text {table }}$ then $\mathrm{H}_{0}$ is rejected, $\mathrm{H}_{\mathrm{a}}$ is accepted

b. If $\mathrm{t}_{\text {count }}<\mathrm{t}_{\text {table }}$ then $\mathrm{H}_{0}$ is accepted, $\mathrm{H}_{\mathrm{a}}$ is rejected

\section{Simultaneous Test (f Test)}

The statistical $\mathrm{f}$ test is used to test all the independent variables studied, whether it has simultaneous influence on the dependent variable. It is done by comparing $\mathrm{f}_{\text {count }}$ with $\mathrm{f}_{\text {table }}$ with a significant level $(\alpha)$ of 0.05 or $5 \%$ on the following criteria:

$\mathrm{H}_{0} 4: \beta_{4}=0$ there is no effect between Islamic knowledge, career development, and compensation on the students' career interests in Islamic financial institutions.

$\mathrm{H}_{0} 4: \beta 4 \neq 0$ there is influence between Islamic knowledge, career development, and compensation on the students' career interests in Islamic financial institutions.

\section{RESULTS AND DISCUSSION}

Validity test is done by product moment correlation analysis. Based on table 1, all statement items are declared valid.

Table 1 Validity Test Result 


\begin{tabular}{|l|l|l|l|l|}
\hline & Item Pertanyaan & Koefisien Korelasi (rxy) & r tabel & Keterangan \\
\hline Vengetahuan Syariahel & $\mathrm{X}_{1.1}$ & 0,346 & 0,3 & Valid \\
\hline & $\mathrm{X}_{1.2}$ & 0,712 & 0,3 & Valid \\
\hline & $\mathrm{X}_{1.3}$ & 0,506 & 0,3 & Valid \\
\hline & $\mathrm{X}_{1.4}$ & 0,367 & 0,3 & Valid \\
\hline & $\mathrm{X}_{1.5}$ & 0,673 & 0,3 & Valid \\
\hline & $\mathrm{X}_{1.6}$ & 0,605 & 0,3 & Valid \\
\hline & $\mathrm{X}_{1.7}$ & 0,608 & 0,3 & Valid \\
\hline & $\mathrm{X}_{2.1}$ & 0,559 & 0,3 & Valid \\
\hline & $\mathrm{X}_{2.2}$ & 0,698 & 0,3 & Valid \\
\hline & $\mathrm{X}_{2.3}$ & 0,604 & 0,3 & Valid \\
\hline & $\mathrm{X}_{2.4}$ & 0,514 & 0,3 & Valid \\
\hline & $\mathrm{X}_{2.5}$ & 0,601 & 0,3 & Valid \\
\hline & $\mathrm{X}_{2.6}$ & 0,618 & 0,3 & Valid \\
\hline $\mathrm{X}_{2.7}$ & 0,397 & 0,3 & Valid \\
\hline & $\mathrm{X}_{3.1}$ & 0,692 & 0,3 & Valid \\
\hline & $\mathrm{X}_{3.2}$ & 0,704 & 0,3 & Valid \\
\hline & $\mathrm{X}_{3.3}$ & 0,765 & 0,3 & Valid \\
\hline & $\mathrm{X}_{3.4}$ & 0,666 & 0,3 & Valid \\
\hline & $\mathrm{X}_{3.5}$ & 0,826 & 0,3 & Valid \\
\hline & $\mathrm{X}_{3.6}$ & 0,674 & 0,3 & Valid \\
\hline & $\mathrm{X}_{3.7}$ & 0,748 & 0,3 & Valid \\
\hline Komgembangan Karir & $\mathrm{Y}_{1.1}$ & 0,788 & 0,3 & Valid \\
\hline & $\mathrm{Y}_{1.2}$ & 0,879 & 0,3 & Valid \\
\hline $\mathrm{Y}_{1.3}$ & 0,917 & 0,3 & Valid \\
\hline & $\mathrm{Y}_{1.4}$ & 0,566 & 0,3 & Valid \\
\hline & $\mathrm{Y}_{1.5}$ & 0,404 & 0,3 & Valid \\
\hline & $\mathrm{Y}_{1.6}$ & 0,919 & 0,3 & Valid \\
\hline & $\mathrm{Y}_{1.7}$ & 0,875 & 0,3 & Valid \\
\hline & & & & \\
\hline
\end{tabular}

Reliability test is carried out to find out the consistency of the measurement results of the variables. A variable is said to be reliable if it gives a Cronbach Alpha value of $\geq 0.6$ (Ghozali, 2016). Based on the results of the reliability test in table 2, all four variables are greater than 0.6 .

Table 2 Reliability Test Result

\begin{tabular}{|c|c|c|c|}
\hline Variabel & Alpha Crobach & Nilai kritis & Keterangan \\
\hline Pengetahuan syariah & 0,644 & $>0,60$ & Reliabel \\
\hline Pengembangan karir & 0,609 & $>0,60$ & Reliabel \\
\hline Kompensasi & 0,84 & $>0,60$ & Reliabel \\
\hline Minat Mahasiswa Berkarir diLKS & 0,89 & $>0,60$ & Reliabel \\
\hline
\end{tabular}

The results of multiple regression model tests on the factors that affect the accounting students' career interests in Islamic financial institutions as presented in table $\mathbf{3}$ can be described in the multiple linear regression equation as follows:

$$
\mathrm{Y}=1.034+0.814 \mathrm{X}_{1}+0.488 \mathrm{X}_{2}-0.291 \mathrm{X}_{3}
$$

The above equation can be interpreted as follows:

1.034 means that if the variables $X_{1}, X_{2}$ and $X_{3}$ are 0 , then the $Y$ variable will be worth 1.034 units. 
$\beta_{1}=0.814$ means that if it increases by 0.814 and the other variables are constant, then the Y variable will increase by 0.814 units.

$\beta_{2}=0.488$ means that if it increases by 0.488 and the other variables are constant, then the $\mathrm{Y}$ variable will increase by 0.488 units.

$\beta_{3}=-0.291$ means that if it increases by -0.291 and the other variables are constant, then the Y variable will decrease by -0.291 units.

Table 3 Multiple Regression Analysis Result

\begin{tabular}{|c|c|c|c|c|c|}
\hline \multirow{3}{*}{ Model } & \multicolumn{2}{|c|}{ Unstandardized } & \multicolumn{3}{|l|}{ Standardized } \\
\hline & Coeffici & & Coefficients & t & $\mathrm{Sio}$ \\
\hline & B & $\begin{array}{l}\text { Std. } \\
\text { Error }\end{array}$ & Beta & & \\
\hline 1 (Constant) & 1,034 & 4,641 & & 0,223 & 0,83 \\
\hline Islamic knowledge & 0,814 & 0,231 & 0,525 & 3,525 & 0 \\
\hline Career development & 0,488 & 0,341 & 0,35 & 1,432 & 0,16 \\
\hline Compensation & $-0,291$ & 0,264 & $-0,259$ & $-1,1$ & 0,28 \\
\hline
\end{tabular}

Table 4 Correlation Coefficient Analysis Result

\begin{tabular}{|c|r|r|r|r|}
\hline & & & & \\
\hline Model & R & R square & Adjusted R Square & Std. Error of the Estimate \\
\hline 1 &, $616^{\mathrm{a}}$ & 0,379 & 0,329 & 3,973 \\
\hline
\end{tabular}

Based on table 4, it can be seen that the correlation coefficient $(\mathrm{R})$ is 0.616 . Based on this value, it shows that there is a strong relationship between the independent variable and the dependent variable. After knowing the correlation coefficient (R) is 0.616 , the coefficient of determination can be calculated using following formula

$\mathrm{Kd}=\mathrm{R}^{2} \times 100 \%$

$=(0,616)^{2} \times 100 \%$

$=37,9 \%$ 
Based on the results of these calculations, the coefficient of determination is obtained by $37.9 \%$. It can be concluded that Islamic knowledge, career development, and compensation have a simultaneous effect of $37.9 \%$ on the students' career interests in Islamic financial institutions. Meanwhile, the remaining $62.1 \%$ is influenced by other factors not examined by the writers.

Based on the calculation of the partial hypothesis test presented in table 4 , if $t_{\text {count }}>$ $t_{\text {table }}$ then $\mathrm{H}_{0}$ is rejected, $\mathrm{H}_{\mathrm{a}}$ is accepted and if $\mathrm{t}_{\text {count }}<\mathrm{t}_{\text {table }}$ then $\mathrm{H}_{0}$ is accepted, $\mathrm{H}_{\mathrm{a}}$ is rejected. The data shows that the value of $t_{\text {table }}$ is 2.026 , then it can be concluded that variable $\mathrm{X}_{1}$ (Islamic knowledge) with $t_{\text {count }}$ of $3.525 t_{\text {count }}>t_{\text {table }}$ then $\mathrm{H}_{0}$ is rejected, $\mathrm{H}_{\mathrm{a}}$ is accepted meaning that variable $\mathrm{X}_{1}$ has significant influence on variable $\mathrm{Y}$ (students' career interests in Islamic financial institutions). Therefore, it can be said that having good Islamic knowledge will affect students' interests in determining their career in Islamic Financial Institutions. The results of this study are in line with previous studies conducted by Fani Andrian Permana (2015). The effect of positive values shows that having good Islamic knowledge tends to give a positive response to students and is able to encourage accounting students of regular afternoon class of 2015 at Sangga Buana University YPKP to choose their career in Islamic financial institutions.

While variable $\mathrm{X}_{2}$ (career development) and variable $\mathrm{X}_{3}$ (compensation) are on the value of $t_{\text {count }}<t_{\text {table }}$ then $\mathrm{H}_{0}$ is accepted, $\mathrm{H}_{\mathrm{a}}$ is rejected, it means that the variables do not significantly affect the students' interests in determining their career in Islamic Financial Institutions. This can be due to students' perceptions of individual career development with the aim of moving companies as a career development strategy does not guarantee a better career opportunity. Along with variable $\mathrm{X}_{2}$, variable $\mathrm{X}_{3}$ i.e. compensation does not have significant influence on the students' interests in a career in Islamic financial institutions. This result is not in line with a previous study conducted by Rifqi Muhammad (2017) in statistical tests that show financial awards/salaries has an influence on student's interests in a career in Islamic financial institutions. Compensation provided in any form by the organization does not affect the interests of the students to determine their careers in Islamic financial institutions; it can be because students do not question the compensation given by the organization because basically students will still choose to work in Islamic financial institutions regardless of how much the compensation is.

Based on the results of statistical processing of simultaneous hypothesis test (f test), the value of $f_{\text {count }}$ is 7.524 which is greater than the value of $f_{\text {table }}$ that is 2,85 . In addition, a significant value obtained by $0,000<0.05$ means that the independent variables (Islamic knowledge, career development, and compensation) simultaneously have significant influence on the dependent variable (students' career interests in Islamic financial institutions). This is supported by a statement to respondents, that good Islamic knowledge, career development either planned individually or by career management in the organization, and compensation in any form provided by the organization can be an alternative choice in determining their career which then raises students' interests in determining their career in Islamic financial institution.

\section{CONCLUSION}


Based on the results of the statistical tests and discussion which have been described, it shows that all variables of Islamic knowledge, career development, and compensation simultaneously have significant influence on variable of students' career interests in Islamic financial institutions with a total contribution of $37.9 \%$ while the remaining $62,1 \%$ is the influence of other factors which are not observed in this study. Meanwhile, the partial test on variable of Islamic knowledge has significant positive effect on the students' interests in a career in Islamic financial institutions, while variable of career development and compensation do not have partial effect on the students' career interests in Islamic financial institutions. From this explanation, it can be considered by universities to add Islamic-based courses or to found faculties with Islamic concentration. The opening of the sharia department aims to provide human resources capability to support improvement of the quality and quantity of Islamic financial institutions.

\section{REFERENCES}

Abou-Youssef, M.M.H.,Kortam, W., Abou-Aish., \& El-Bassiouny, N. (2015). Effects of religiosty on consumer attitudes toward Islamic banking in Egypt. International Journal of Bank Marketing, 33(6), 786-807

Andrian (2015). Factors that influence the interest of Bengkulu University accounting students career in Sharia Entities. Journal of Economics and Business Bengkulu University

Djamarah, Syaiful Bahri. (2008). Psychology of Learning. PT. Rineka Cipta. Jakarta

Ghozali, Imam. (2016). Aplikasi Analisis Multivariate dengan Program IBM SPSS 23. Semarang: BPFE Universitas Diponegoro

Kasmir. (2015). Human Resource Management. PT RAJAGRAFINDO PERSADA

Kompas. 2012. The three biggest problems in Islamic banks. Retrieved 24 January2019, from https://ekonomi.kompas.com/read/2012/08/13/15282835/Tiga.Masalah.Terbesar.d i.Bank.SyariahIndonesia (2003).

Merdekawati, D. P., \& Sulistiawati, A (2011). Faktor-Faktor yang Mempengaruhi Pemilihan Karir Akuntan Publik dan Non Akuntan Publik. Jurnal Ilmu Ekonomi Aset. 13(1), 9-19

Nurhayati, S \& Wasilah (2009). Akuntansi Syariah di Indonesia. Jakarta. Salemba Empat

Rifki Muhammad. (2017). Factors that influence student interest in working at Islamic Financial Institutions. Journal of Islamic Economics \& Finance. Vol.3 No.2 
Sugiyono. (2016). Quantitative, Qualitative, and R\&D Research Methods. ALFABETA,cv

Sutrisna, Anna S. dan Muchlis, Saiful. (2016). Factors affecting accounting students interest in a career in the Islamic Financial Services Institute. Indonesian Journal of Accounting and Finance Research, 1

Suwatno \&Donni. (2016). Human Resource Management. Alfabeta, cv.

Suyono, Nanang Agus. (2014). Analysis of the factors that influence career selection as a public accountant. PPKM Journal II: 69-83 